\title{
A LIFE-COURSE PERSPECTIVE ANALYSIS ON THE FACTORS AFFECTING NEONATAL DEATH IN BANTUL DISTRICT, YOGYAKARTA
}

\author{
Funik Rahma Mei Listiani'), Harsono Salimo²), Bhisma Murti1) \\ 1)Masters Program in Public Health, Universitas Sebelas Maret \\ ${ }^{2)}$ Department of Pediatrics, Dr. Moewardi Hospital, Surakarta
}

\begin{abstract}
Background: Neonatal death is an important health outcome during the first year of life. According to WHO, 46\% of deaths among children under five were newborns in 2016. Neonatal death rates reflect economic and social conditions for the health of mothers and newborns, as well as the effectiveness of health system. Little is known, however, about the biological and socio economic factors that affect neonatal death in Indonesia. This study aimed to determine the factors affecting neonatal death in Bantul District, Yogyakarta, with a life-course perspective.

Subjects and Method: This was a case-control study conducted in Panembahan Senopati Hospital, from January 2017 to January 2018. A total sample of 200 neonates was selected for this study by fixed disease sampling, consisting of 50 dead and 150 alive neonates. The dependent variable was neonatal death. The independent variables were low birth-weight, asphyxia, prematurity, pregnancy infection, maternal age, maternal education, maternal employment status, and family income. The data were collected by questionnaire and analyzed by path analysis.

Results: The risk of neonatal death increased with asphyxia $(b=3.65 ; 95 \% \mathrm{CI}=$ 1.77 to $5.52 ; \mathrm{p}<0.001)$, prematurity $(\mathrm{b}=2.78 ; 95 \% \mathrm{CI}=1.64$ to $3.92 ; \mathrm{p}<0.001)$, and infection $(b=3.04 ; 95 \% \mathrm{CI}=1.82$ to $4.26 ; \mathrm{p}<0.001)$. The risk of neonatal death increased withlow birthweight, but decreased with maternal age 20-35 years, high family income, high maternal education, and mother working outside the house.

Conclusion: The risk of neonatal death increased with asphyxia, prematurity, low birth weight, infection, maternal age $<20$ or $\geq 35$ years, low maternal education, maternal employment outside the house, and low family income.
\end{abstract}

Keywords: neonatal death, risk factors, biolygical factor, social and economic factor

\section{Correspondence:}

Funik Rahma Mei Listiani, Masters Program in Public Health, Universitas Sebelas Maret, Jl. Ir. Sutami 36 A, Surakarta 57126, Central Java.

Email: funikrahmameilistiani@gmail.com. 